\title{
Electrodeposition of copper from mixed sulphate-chloride acidic electrolytes at rotating disc electrode
}

\author{
C. T. J. Low ${ }^{1,2}$, C. Ponce de Leon ${ }^{1}$ and F. C. Walsh*1
}

The effect of chloride ion on the deposition of copper from low metal concentrations in aqueous, acid sulphate solutions was investigated. The electrolytes contained $0.05 \mathrm{~mol} \mathrm{dm}^{-3} \mathrm{CuSO}_{4}$ and $0.5 \mathrm{~mol} \mathrm{dm}^{-3} \mathrm{Na}_{2} \mathrm{SO}_{4}$ at $\mathrm{pH} 2$ and $296 \mathrm{~K}$. The chloride ion concentration was varied in a wide range from 0.03 to $2.0 \mathrm{~mol} \mathrm{dm}^{-3}$. Linear sweep voltammetry was carried out under well defined flow conditions at a smooth platinum rotating disc electrode. The progressive transition from a single, two-electron reaction for the reduction of $\mathrm{Cu}(\mathrm{II}) \rightarrow \mathrm{Cu}(0)$ to two, single-electron reactions for the reduction sequence: $\mathrm{Cu}(\mathrm{II}) \rightarrow \mathrm{Cu}(\mathrm{I}) \rightarrow \mathrm{Cu}(0)$ was clearly evident as the chloride ion concentration increased. The charge transfer and mass transport characteristics of these reactions were evaluated. The formal potential for the $\mathrm{Cu}(\mathrm{II})$ reduction to $\mathrm{Cu}(\mathrm{I})$, the shift in the potential region for complete mass transport controlled reduction of $\mathrm{Cu}(\mathrm{I})$ to $\mathrm{Cu}(0)$ and the potential for hydrogen evolution at the deposited copper were also studied. A semi-logarithmic relationship between exchange current density and half-wave potential for $\mathrm{Cu}(\mathrm{II}) \rightarrow \mathrm{Cu}(\mathrm{I})$ with chloride ion was achieved when the $\mathrm{Cl}^{-} / \mathrm{Cu}(\mathrm{II})$ ratio in the electrolytes exceeded 2, due to the presence of the $\mathrm{Cu}(\mathrm{I})$ dichlorocuprous anion, $\mathrm{CuCl}_{2}^{-}$.

Keywords: Charge transfer, Chloride ion, Copper deposition, Exchange current density, Formal potential, Hydrogen evolution, Mass transport, Rotating disc electrode, Sulphate ion

\section{List of symbols}

$\alpha$ Charge transfer coefficient, dimensionless

$b$ Tafel slope, $\mathrm{V}$ decade ${ }^{-1}$

$c_{\mathrm{Cl}^{-}}$Concentration of chloride ion in the electrolyte, $\mathrm{mol} \mathrm{dm}^{-3}$

$c_{\mathrm{Cu}^{2+}}$ Concentration of $\mathrm{Cu}(\mathrm{II})$ in the electrolyte, mol dm ${ }^{-3}$

E Electrode potential versus $\mathrm{Ag} \mid \mathrm{AgCl}, \mathrm{V}$

$\left.E_{\mathrm{e}}^{\mathrm{o}}\right|_{\mathrm{Cl}^{-}} \quad$ Formal potential of copper in the presence of chloride ion, $\mathrm{V}$

$F$ Faraday constant, $\mathrm{C} \mathrm{mol}^{-1}$

$j$ Current density, $\mathrm{A} \mathrm{cm}^{-2}$

$j_{\mathrm{L}} \quad$ Limiting current density, $\mathrm{A} \mathrm{cm}^{-2}$

$j_{\mathrm{o}}$ Exchange current density, $\mathrm{A} \mathrm{cm}^{-2}$

$k$ Rate constant, $\mathrm{s}^{-1}$

$n$ Stoichiometric number in reaction (4), dimensionless

$R \quad$ Molar gas constant, $\mathrm{J} \mathrm{K}^{-1} \mathrm{~mol}^{-1}$

$S$ Nernstian slope in equation (15), V

$T$ Temperature, $\mathrm{K}$

${ }^{1}$ Electrochemical Engineering Laboratory, Engineering Sciences, University of Southampton, Highfields, Southampton, SO17 1BJ, UK

${ }^{2}$ Present address: WMG Centre, School of Engineering, University of Warwick, Coventry, CV4 7AL, UK

*Corresponding author, email F.C.Walsh@soton.ac.uk $z$ Number of electrons involved in the electrode reaction, dimensionless

\section{Subscripts}
a Anodic
$b$ Cathodic
e Equilibrium
$\mathrm{Cl}^{-}$Chloride ions
$\mathrm{Cu}^{2+} \mathrm{Cu}(\mathrm{II})$ ions

L Limited by convective diffusion mass transport

\section{Introduction}

Electrodeposition of copper is often carried out under controlled flow conditions. For laboratory investigations, rotating electrodes have been used as experimental tools for electroanalytical and mechanistic studies of electrochemical reactions. There are many types of rotating electrode geometries considered such as single electrode, roughened electrodes, bi-electrode systems and other electrodes. ${ }^{1}$ Among these electrode geometries, the rotating disk electrode (RDE) and the rotating cylinder electrode (RCE) are the most frequently used electrodes for laboratory and industrial investigations. Such electrodes are hydrodynamic tools that use forced convection to enhance the mass transport rate to the electrode surface. The introduction of forced convection to the electrode surface results in increased current 
density and sensitivity. In practice, the hydrodynamically smooth rotating disk electrode generally operates in laminar flow, while the rotating cylinder electrode normally operates in turbulent flow. ${ }^{1}$

Many studies have been undertaken on the electrodeposition of copper; due to its diverse applications, e.g. electrical contacts and solder components for the electronics industry, undercoats for nickel and chromium plating and as a decorative finish. Various acidic electrolyte formulations are available, including sulphate-, fluroborate-, cyanide-, pyrophosphate- and sulfonate baths. ${ }^{2,3}$ Pyrophosphate and cyanide solutions have been used to deposit copper at low to medium current densities whereas acid sulphate and fluroborate solutions tend to be used at higher plating rates while methanesulphonic acid electrolytes have been used at a high current density and at a high copper ion concentration., ${ }^{4,5}$

A wide range of additives has been investigated for the electrodeposition of copper from an acid sulphate electrolyte. In the electronics and electrical industries, additives can include suppressors, accelerators and levellers to produce desirable coatings. ${ }^{6}$ Common examples include polypropylene glycol, ${ }^{7-9}$ bis(3-sulphopropyl) disulphide, nitrogen containing aromatic compounds, ${ }^{10,11}$ thiourea, ${ }^{12}$ gelatine, ${ }^{13}$ 3-mercapto-1propanesulphonate ${ }^{14,15}$ and chloride ion. ${ }^{16}$ Such chemicals are added in small quantities and can realise an improved deposit quality involving the appearance of the plated metal (surface brightness), a modified coating structure together with physical properties (e.g. improved corrosion resistance, wear and electrical conductivity), grain refinement and suppression of dendritic growth together with improved covering and throwing power.

Chloride ion has a significant effect on the copper deposition. For example, an addition of a low chloride ion concentration, e.g. 50-200 ppm, is generally used for copper electroplating ${ }^{17}$ and 1 to $2 \times 10^{-3} \mathrm{~mol} \mathrm{dm}^{-3}$ used in the electronics and electrical industries. ${ }^{18} \mathrm{~A}$ higher chloride ion concentration $\left(0 \cdot 1-3 \cdot 0 \mathrm{~mol} \mathrm{dm}{ }^{-3}\right)$ is used in copper electrowinning; levels up to $9.0 \mathrm{~mol} \mathrm{dm}^{-3}$ are used for copper refining in hydrothermal systems ${ }^{19}$ and $280 \mathrm{~g} \mathrm{dm}^{-3}$ used in the leaching of copper from copper mineral chalcopyrite. ${ }^{20}$ In most cases, chloride ion is added as a supplement to other additives to achieve combinatorial effects. For example, in the absence of other additives, $\mathrm{Cl}^{-}$will promote the reduction of copper at a more positive electrode potential. ${ }^{20}$ In the presence of both $\mathrm{Cl}^{-}$and polyethylene glycol (PEG), however, the copper reduction may be inhibited to a more negative potential and the $\mathrm{Cl}^{-}$ion may assist in the formation of spherical PEG molecules and monolayer adsorption of PEG. ${ }^{8,9,13,22-24}$

The present work considers relatively dilute $<50 \mathrm{mmol} \mathrm{dm}^{-3}$ copper solutions which are found in rinse waters and environmental wastes. The effect of chloride ion on copper deposition in mixed chloridesulphate electrolytes at a constant $\mathrm{pH}$ of 2 is investigated using a rotating disc electrode. The presence of chloride ion is considered to form various complex formations with the copper ion, e.g. $\mathrm{CuCl}^{+}, \mathrm{CuCl}_{2}^{-}, \mathrm{CuCl}_{3}^{1-}$ and $\mathrm{CuCl}_{4}^{2-}{ }^{24,25}$ In most cases, the redox reaction of $\mathrm{Cu}(\mathrm{II})$ to $\mathrm{Cu}(\mathrm{I})$ is investigated. ${ }^{25,27}$ In sulphate electrolytes, the reduction of $\mathrm{Cu}(\mathrm{II})$ to $\mathrm{Cu}(0)$ may involve a single, twoelectron reduction step

$$
\mathrm{Cu}^{2+}+2 e^{-} \rightarrow \mathrm{Cu}
$$

This reversible reaction has a standard potential of $0 \cdot 34 \mathrm{~V}$ (SHE).

In chloride electrolytes, copper(I) is stabilised in the reduction sequence $\mathrm{Cu}(\mathrm{II})$ to $\mathrm{Cu}(\mathrm{I})$ to $\mathrm{Cu}(0),{ }^{28-30}$ the reduction of $\mathrm{Cu}(\mathrm{II})$ to $\mathrm{Cu}(0)$ may involve an intermediate step

$$
\begin{aligned}
& \mathrm{Cu}^{2+}+e^{-} \rightarrow \mathrm{Cu}^{+} \\
& \mathrm{Cu}^{+}+n \mathrm{Cl}^{-} \rightarrow \mathrm{CuCl}_{\mathrm{n}}^{1-n}
\end{aligned}
$$

The overall reaction becomes

$$
\mathrm{Cu}^{2+}+n \mathrm{Cl}^{-}+e^{-} \rightarrow \mathrm{CuCl}_{\mathrm{n}}^{1-\mathrm{n}}
$$

The second step for the reduction of $\mathrm{Cu}(\mathrm{I})$ ions to copper metal, $\mathrm{Cu}(0)$, may then proceed via

$$
\mathrm{CuCl}_{\mathrm{n}}^{1-\mathrm{n}}+\mathrm{e}^{-} \rightarrow \mathrm{Cu}+\mathrm{nCl}^{-}
$$

where $n$ is the stoichiometric number for chloride ion. The formation of cuprous chloro-complexes will depend on the concentration of chloride ion in the electrolyte. The stabilisation of $\mathrm{Cu}(\mathrm{I})$ with chloride ion is evidenced by the high value of its critical stability constant $(K)$. For $\mathrm{Cu}$ (I) chloro-complexes, $\log K=5 \cdot 19$ whereas for $\mathrm{Cu}(\mathrm{II})$ chloro-complexes, $\log K=0 \cdot 09,{ }^{7}$ i.e. the chloride ion interacts strongly with $\mathrm{Cu}$ (I) but weakly with $\mathrm{Cu}$ (II).

Electrodeposition of copper from an electrolyte containing chloride ion has been studied at platinum $^{31}$ and gold rotating ring disc electrodes. ${ }^{32}$ Both studies demonstrated that $\mathrm{Cu}(\mathrm{I})$ is less stable in $\mathrm{SO}_{4}{ }^{2-}$, but in the presence of $\mathrm{Cl}^{-}$, the $\mathrm{Cu}(\mathrm{II})$ is stabilised and the reaction on the disc gave two separate, single electron waves. In this work, the authors have used a wide range of chloride ion to copper ion concentration ratios to investigate the progressive changes in copper reduction. Such high chloride ion levels are commonly encountered in electrowinning and the recovery of copper from aqueous effluents by electrodeposition. Linear sweep voltammetry has been carried out at a rotating disc electrode enabling the charge transfer and mass transport characteristics of copper depositions to be evaluated. The change in the limiting current density and the number of electrons involved have been investigated. The open-circuit and half-wave potentials of $\mathrm{Cu}$ (II) to $\mathrm{Cu}(\mathrm{I})$ were also considered. The effects of chloride ion on the exchange current density, the potential region for complete mass transport controlled reduction of $\mathrm{Cu}(\mathrm{I})$ to $\mathrm{Cu}(0)$ and the potential for hydrogen evolution have also been studied. An earlier paper in this journal ${ }^{31}$ considered copper deposition from $20-50 \mathrm{mM} \mathrm{CuSO}_{4}+1 \cdot 5 \mathrm{M} \mathrm{NaCl}$ at $\mathrm{pH} 2$ and $293 \mathrm{~K}$. The present work involves an $\mathrm{Na}_{2} \mathrm{SO}_{4}$ electrolyte to which $\mathrm{Cl}^{-}$ions are added; this study greatly extends the concentration ranges of chloride ions and dissolved copper, hence their molar ratio together with the use of simple voltammetry techniques to study the kinetics of copper deposition from chloride containing acid sulphate solutions

\section{Experimental}

Copper was deposited from an electrolyte containing $0.05 \mathrm{~mol} \mathrm{dm}^{-3}$ copper sulphate $\left(99.995 \% \mathrm{CuSO}_{4}\right)$ and 
$0.5 \mathrm{~mol} \mathrm{dm}^{-3}$ sodium sulphate $\left(99 \cdot 995 \% \mathrm{Na}_{2} \mathrm{SO}_{4}\right)$ at $296 \mathrm{~K}$ corrected to $\mathrm{pH} 2$ using $\mathrm{H}_{2} \mathrm{SO}_{4}$. Various concentrations of sodium chloride (from 0.03 to $2 \cdot 0 \mathrm{~mol} \mathrm{dm}^{-3} 99 \cdot 995 \% \mathrm{NaCl}$ ) were pipetted into the electrolyte prior to each experiment. All chemical reagents were analytical grade and supplied by Fischer Chemical UK Ltd. A conventional three-electrode, glass cell was used (150 $\mathrm{cm}^{3}$ volume). The working electrode was a circular disc electrode consisting of a platinum $\left(99.995 \%\right.$ purity, $2 \mathrm{~mm}$ radius, $0.126 \mathrm{~cm}^{2}$ nominal surface area) surrounded by a PTFE shroud $(6 \mathrm{~mm}$ radius). The counter electrode was a platinum mesh (99.995\% purity, $1 \mathrm{~cm}$ length $\times 1 \mathrm{~cm}$ width, $0.25 \mathrm{~mm}$ nominal aperture), and was placed in a glass tube compartment containing the background electrolyte of $0.5 \mathrm{~mol} \mathrm{dm}^{-3} \mathrm{Na}_{2} \mathrm{SO}_{4}$ corrected to $\mathrm{pH} 2$ with $\mathrm{H}_{2} \mathrm{SO}_{4}$. It was separated from the main electrolyte by a Nafion $\left(\mathrm{NF} 115 / \mathrm{H}^{+}\right)$cation membrane. The reference electrode was silver|silver chloride electrode, $\mathrm{Ag} \mid \mathrm{AgCl}$ in the Luggin capillary compartment, which contained an agar-agar gel of $0.5 \mathrm{~mol} \mathrm{dm}{ }^{-3} \mathrm{Na}_{2} \mathrm{SO}_{4}$ corrected to pH 2 with $\mathrm{H}_{2} \mathrm{SO}_{4}$. This arrangement provided a low liquid junction potential and minimised further chloride contamination of the working electrode compartment due to leakage of the reference electrode filling solution.

The platinum disc electrode was wet-polished with $3 \mu \mathrm{m} \mathrm{Al}{ }_{2} \mathrm{O}_{3}$ then $0 \cdot 15 \mu \mathrm{m} \mathrm{SiO}_{2}$ particles on a LeCloth polishing substrate. The disc surface, which was cleaned and ultrasonicated with ultrapure water to remove particulates, was freshly polished before each experiment and used immediately. The platinum RDE active surface was placed $2 \mathrm{~mm}$ from the tip ( $1 \mathrm{~mm}$ diameter) of the Luggin capillary and positioned centrally in the three-electrode cell. Electrolyte temperature was maintained at $296 \mathrm{~K}$. A fast stream of nitrogen gas was bubbled through the electrolyte for $10 \mathrm{~min}$ before each experiment to remove dissolved oxygen and a nitrogen gas blanket was maintained over the surface of the electrolyte. Linear sweep voltammetry was performed using a platinum rotating disk electrode at $800 \mathrm{rev} \mathrm{min}^{-1}$, the electrode potential was swept from +0.9 to $-1.0 \mathrm{~V}$ versus $\mathrm{Ag} \mid \mathrm{AgCl}$ at $16 \mathrm{mV} \mathrm{s}^{-1}$. The open-circuit potential measurement was obtained at a static disc electrode after $10 \mathrm{~min}$ immersion time in the electrolyte. All electrochemical measurements were made with an EcoChemie Autolab potentiostat (PGSTAT20) using the General Purpose, Electrochemical Software, GPES Version 4.5.

\section{Results and discussion}

Figure 1 shows the linear sweep voltammetry for copper deposition at the platinum rotating disc electrode (a) sulphate bath and (b) to (f) mixtures of chloride and sulphate electrolytes. The platinum RDE was rotated at $800 \mathrm{rev} \mathrm{min}^{-1}$ and the electrode potential was linearly swept from +0.9 to $-1.0 \mathrm{~V}$ versus $\mathrm{Ag} \mid \mathrm{AgCl}$ at $16 \mathrm{mV} \mathrm{s}^{-1}$. In the sulphate bath, a single limiting current density plateau was observed (plateau 1), corresponding to the two electron reduction of $\mathrm{Cu}$ (II) to $\mathrm{Cu}(0)$. In the presence of chloride ion in the electrolytes, the appearance of a second well defined wave and limiting current density can be observed. In Fig. $1 f$, plateau A represents the maximum rate for the reduction of $\mathrm{Cu}(\mathrm{II})$ to $\mathrm{Cu}(\mathrm{I})$ while plateau $\mathrm{B}$ results from the maximum rate of reduction of $\mathrm{Cu}(\mathrm{I})$ to $\mathrm{Cu}(0)$. The
$\mathrm{Cu}(\mathrm{I})$ ion is stabilised by chloride ion and the reduction of $\mathrm{Cu}(\mathrm{II})$ to $\mathrm{Cu}(\mathrm{I})$ to $\mathrm{Cu}(0)$ involves two, single electron steps. The starting potential for the reduction of $\mathrm{Cu}$ (II) to $\mathrm{Cu}(\mathrm{I}) ; \mathrm{Cu}(\mathrm{I})$ to $\mathrm{Cu}(0)$; hydrogen evolution on copper deposits and the limiting current density of $\mathrm{Cu}$ (II) to $\mathrm{Cu}(\mathrm{I})$ and $\mathrm{Cu}(0)$ are shifted with the chloride ion concentration in the electrolytes. Under controlled flow conditions (achieved using the rotating disc electrode), the electrode potential for the first plateau of $\mathrm{Cu}$ (II) to $\mathrm{Cu}(\mathrm{I})$ can be described by ${ }^{33}$

$$
E=\left.E_{\mathrm{e}}^{\mathrm{o}}\right|_{\mathrm{Cl}^{-}}-b_{\mathrm{c}} \log \left(\frac{j_{\mathrm{L}}-j}{j}\right)
$$

where $j_{\mathrm{L}}$ is the limiting current density for $\mathrm{Cu}$ (II) to $\mathrm{Cu}(\mathrm{I}),\left.E_{\mathrm{e}}^{\mathrm{o}}\right|_{\mathrm{Cl}^{-}}$is the formal potential for $\mathrm{Cu}(\mathrm{II})$ to $\mathrm{Cu}(\mathrm{I})$ in the presence of chloride ion, as described by reaction (4) and $b_{\mathrm{c}}$ is the Tafel slope. A plot of $E$ against $\log \left(\frac{j_{\mathrm{L}}-j}{j}\right)$ yielded a linear relationship as shown in Fig. $2 a$ for the reduction of $\mathrm{Cu}(\mathrm{II})$ to $\mathrm{Cu}(\mathrm{I})$. The Tafel slope remained similar for all chloride ion concentration in the electrolytes and was estimated at approximately $-62 \mathrm{mV}$ decade $^{-1}$. Figure $2 b$ shows that the relationship between the measured open-circuit and the half-wave potentials for the reduction of $\mathrm{Cu}$ (II) to $\mathrm{Cu}(\mathrm{I})$ occurred at a more positive potential with an increase of chloride ion in the solution. This effect, i.e. the presence of $\mathrm{Cl}^{-}$led to an acceleration of copper ion reduction, has also been reported in the deposition of copper from a solution containing $0.3 \mathrm{~mol} \mathrm{dm}^{-3} \mathrm{CuSO}_{4}$, $2 \cdot 2 \mathrm{~mol} \mathrm{dm}^{-3} \mathrm{H}_{2} \mathrm{SO}_{4}, 50 \mathrm{ppm}$ (ca. $0 \cdot 0014 \mathrm{~mol} \mathrm{dm}^{-3}$ ) $\mathrm{Cl}^{-}$and $1 \mathrm{~g} \mathrm{dm}^{-3}$ polyethylene glycol. ${ }^{13}$

Figure $2 c$ shows that the initial potential for the reduction of $\mathrm{Cu}(\mathrm{I})$ to $\mathrm{Cu}(0)$ shifted linearly with the logarithmic of chloride ion concentration and that the initial potential for hydrogen evolution on the copper deposits reached a steady state potential, approximately $-0.64 \mathrm{~V}$ versus $\mathrm{Ag} \mid \mathrm{AgCl}$ at increasing chloride ion concentration in the electrolytes. The potential region for complete mass transport controlled reduction of $\mathrm{Cu}(\mathrm{I})$ to $\mathrm{Cu}(0)$ was also shown to vary, being approximately $-115 \mathrm{mV}$ decade $^{-1}$ of logarithmic chloride ion concentration. The deposition potential for the reduction of $\mathrm{Cu}(\mathrm{I})$ to $\mathrm{Cu}(0)$ shifted to more negative potentials and the mass transport control region was shortened at higher chloride ion concentrations. All the findings show that a linear dependence of deposition potential versus $\mathrm{Cl}^{-}$concentration could be obtained at a chloride ion concentration $\left(0 \cdot 1 \mathrm{~mol} \mathrm{dm}^{-3}\right)$ approximately twice that of the copper ion concentration $\left(0.05 \mathrm{~mol} \mathrm{dm}^{-3}\right)$ in the electrolytes.

When the cathodic reaction is under charge transfer control, the kinetics can be approximated by the Tafel equation which shows a linear relationship between the logarithm of the current density and the overpotential ${ }^{33}$

$$
j c=\log j o-b_{\mathrm{c}} \eta
$$

where $b_{\mathrm{c}}$ is the cathodic Tafel slope, $b_{\mathrm{c}}=-2 \cdot 303 \alpha R T /$ $z F T$. For a one-electron change at $296 \mathrm{~K}$ and a transfer coefficient of 0.5 , the theoretical Tafel slope is $-60 \mathrm{mV}$ decade $^{-1}$.

Figure $3 a$ shows the Tafel approximation using the reduction of $\mathrm{Cu}$ (II) to $\mathrm{Cu}(\mathrm{I})$ ions. The Tafel slopes remained unchanged at approximately $-68 \mathrm{mV}$ decade $^{-1}$ and the exchange current density varied in the presence of chloride 

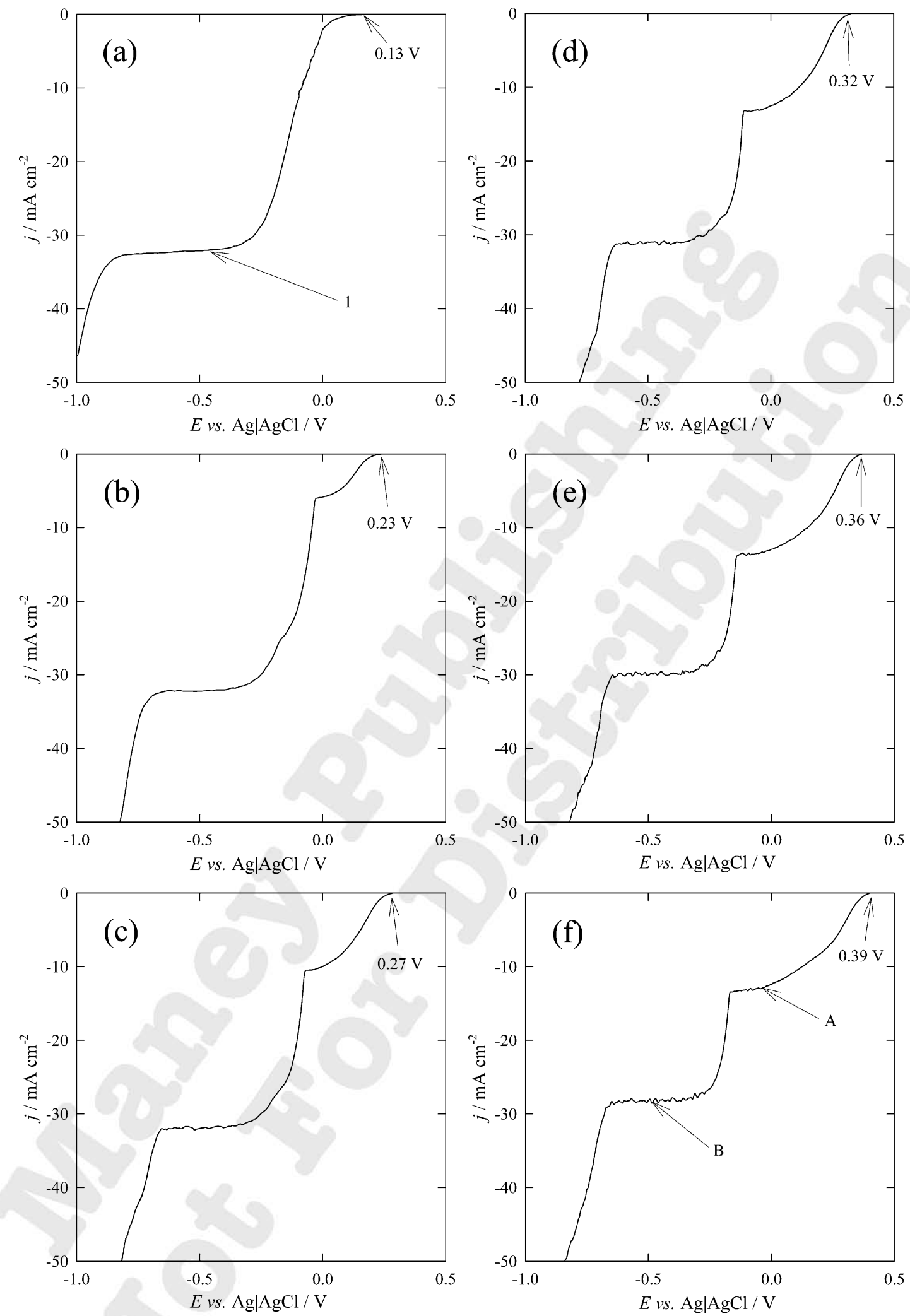

1 Linear sweep voltammetry of copper electrodeposition at controlled flow conditions: platinum RDE was rotated at $800 \mathrm{rev} \mathrm{m^{-1 }}$ and electrode potential was swept from +0.9 to $-1.0 \mathrm{~V}$ versus $\mathrm{Ag} \mid \mathrm{AgCl}$ at $16 \mathrm{mV} \mathrm{s}^{-1}$; a sulphate media and $b-f$ mixed chloride-sulphate electrolytes; $a$ 0, $b \quad 0.12, c 0.32, d 0.69$, e 1.29 and $f 1.92 \mathrm{~mol} \mathrm{dm}^{-3} \mathrm{NaCl}$; base electrolyte contained $0.05 \mathrm{~mol} \mathrm{dm}^{-3} \mathrm{CuSO}_{4}$ and $0.5 \mathrm{~mol} \mathrm{dm}^{-3} \mathrm{Na}_{2} \mathrm{SO}_{4}$ corrected to $\mathrm{pH} 2$ at $296 \mathrm{~K}$; values marked on curves correspond to open-circuit electrode potentials

ion. Figure $3 b$ shows the exchange current density shifted linearly with the logarithmic of chloride ion concentration, starting at chloride ion $\left(0 \cdot 1 \mathrm{~mol} \mathrm{dm}{ }^{-3}\right)$ twice the copper ion concentration $\left(0.05 \mathrm{~mol} \mathrm{dm}^{-3}\right)$ in the electrolyte. A theoretical relationship between the exchange current density and chloride ion concentration can be obtained from the Butler-Volmer equation. At equilibrium, the mass balance for reaction (3) can be written in terms of a flux ${ }^{29}$ 

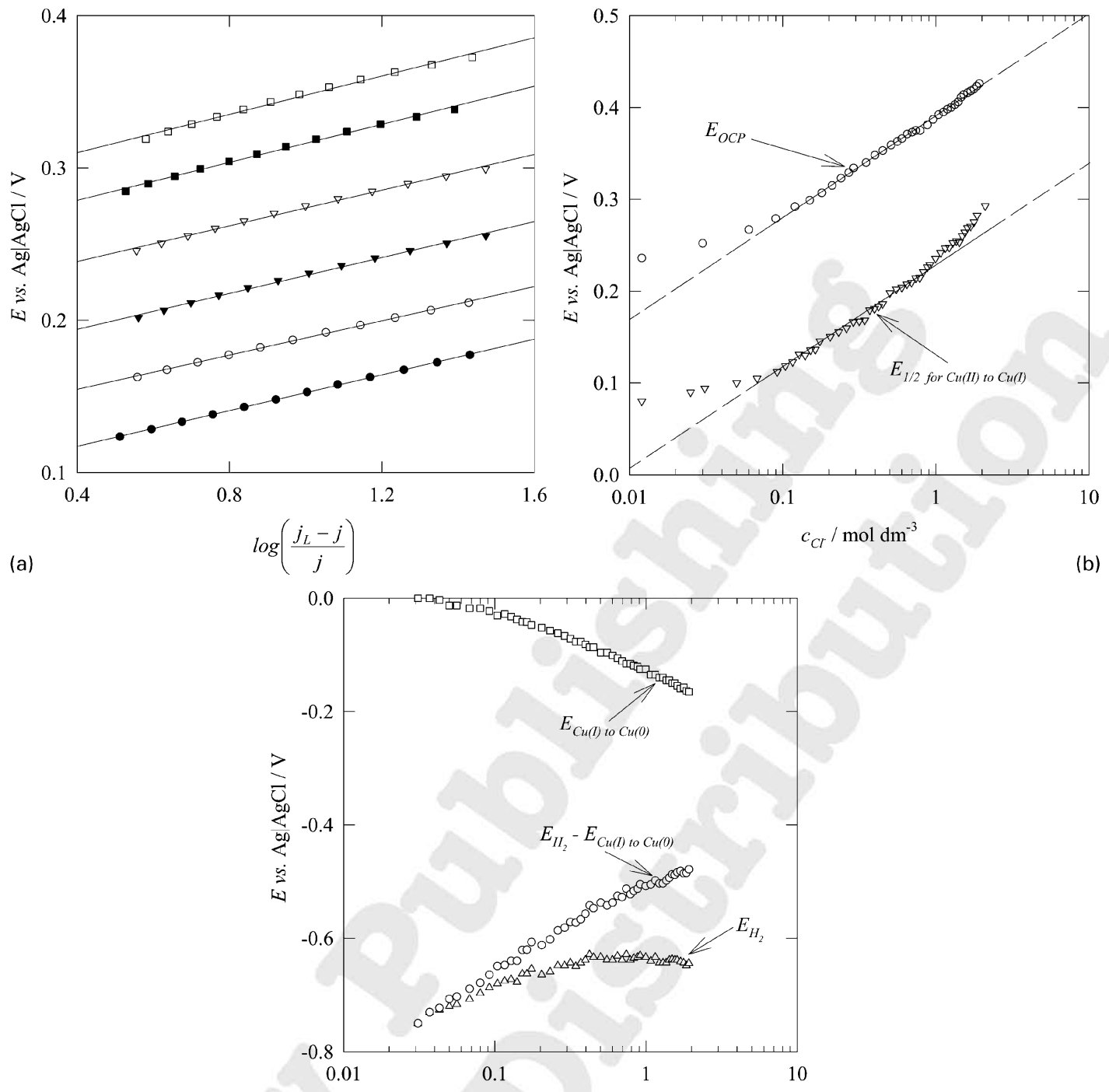

(c)

$c_{C l} / \mathrm{mol} \mathrm{dm}^{-3}$

2 Electrode potential with chloride ion concentration: base electrolyte contained $0.05 \mathrm{~mol} \mathrm{dm}^{-3} \mathrm{CuSO}_{4}$ and $0.5 \mathrm{~mol} \mathrm{dm}$ $\mathrm{Na}_{2} \mathrm{SO}_{4}$ corrected to $\mathrm{pH} 2$ at $296 \mathrm{~K}$ : a expression of Nernstian plot under controlled flow conditions; platinum RDE was rotated at $800 \mathrm{rev} \mathrm{min}^{-1}$ and electrode potential was swept from +0.9 to $-1.0 \mathrm{~V}$ versus $\mathrm{Ag} \mid \mathrm{AgCl}$ at $16 \mathrm{mV} \mathrm{s}{ }^{-1} ; 0.03$, $0.12, \nabla \mathbf{0} 32, \nabla \mathbf{0 . 6 9}, \square 1.29$ and $\square 1.92 \mathrm{~mol} \mathrm{dm}{ }^{-3} \mathrm{NaCl} ; \boldsymbol{b}$ effect of chloride ion on $\bigcirc$ open circuit potential and $\nabla$ half-wave potential of $\mathrm{Cu}(\mathrm{II})$ reduction to $\mathrm{Cu}(\mathrm{I})$; $c$ deposition potential with chloride ion: $\square$ starting potential for the reduction of $\mathrm{Cu}(\mathrm{l})$ to $\mathrm{Cu}(0), \Delta$ hydrogen evolution at copper deposits and $\bigcirc$ potential for the reduction of $\mathrm{Cu}(\mathrm{l})$ to $\mathrm{Cu}(0)$ before hydrogen evolution

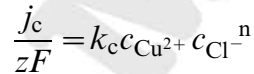

where $j_{\mathrm{c}}$ is the partial current density for cathodic reaction, $z$ is the number of electrons involved in the electrode process, $F$ is Faraday's constant, $k_{\mathrm{c}}$ is the cathodic reaction rate of reaction. Similarly, the anodic flux of copper ions can be described by

$$
\frac{j_{\mathrm{a}}}{z F}=k_{\mathrm{a}} c_{\mathrm{CuCl}_{\mathrm{n}}^{1-\mathrm{n}}}
$$

where $j_{\mathrm{a}}$ is the partial current density for anodic reaction and $k_{\mathrm{a}}$ is the rate constant for the anodic reaction. When the electrode potential is displaced away from the equilibrium, the total current density is the difference between the partial current density of the cathodic and anodic reactions

$$
j=j_{\mathrm{a}}-j_{\mathrm{c}}
$$

The rate of reaction can be expressed in terms of the standard rate of reaction

$$
\begin{aligned}
& k_{\mathrm{a}}=k_{\mathrm{a}}^{\mathrm{o}} \exp \left(\frac{\alpha_{\mathrm{a}} z F E}{R T}\right) \\
& k_{\mathrm{c}}=k_{\mathrm{c}}^{\mathrm{o}} \exp \left(\frac{-\alpha_{\mathrm{c}} z F E}{R T}\right)
\end{aligned}
$$

where $E$ is the electrode potential versus a reference electrode. Equation (12) then becomes 


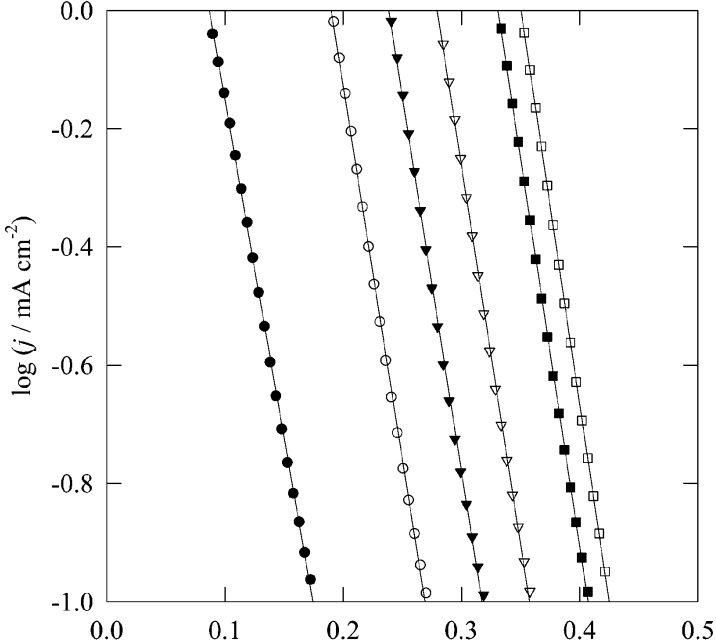

(a)

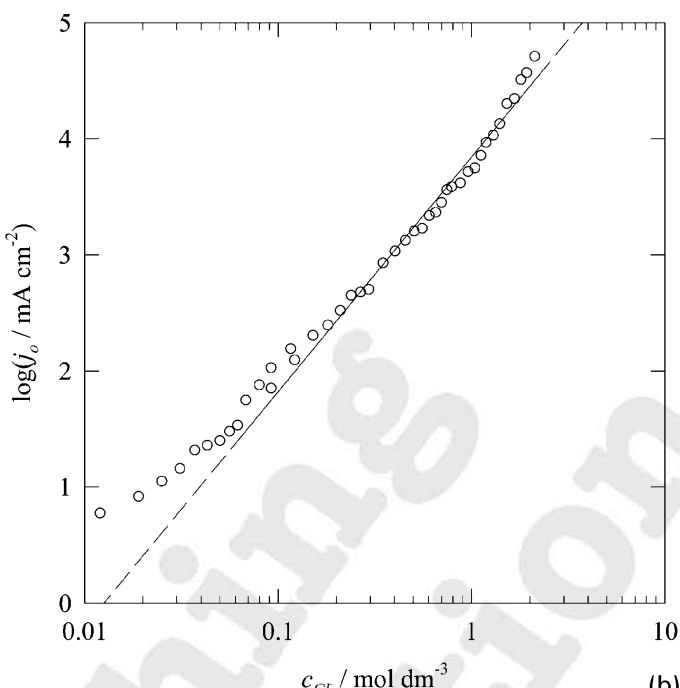

(b)

3 Analysis of copper ion reduction in presence of chloride ion added to sulphate media electrolyte: a Tafel plots of $\mathrm{Cu}(\mathrm{II})$ to $\mathrm{Cu}(\mathrm{I})$ reduction reaction $\bullet 0.03 \mathrm{~mol} \mathrm{dm}^{-3}, \bigcirc \quad 0.18 \mathrm{~mol} \mathrm{dm}^{-3}, \quad \mathbf{0} \quad 0.48 \mathrm{~mol} \mathrm{dm}^{-3}, \nabla \quad 0.74 \mathrm{~mol} \mathrm{dm}^{-3}$, $1.44 \mathrm{~mol} \mathrm{dm}^{-3}$ and $\square 1.86 \mathrm{~mol} \mathrm{dm}^{-3} \mathrm{NaCl}$ and $b$ logarithm of exchange current density versus logarithm of chloride ion concentration

$$
\begin{aligned}
j= & z F k_{\mathrm{a}}^{\mathrm{o}} \exp \left(\frac{\alpha_{\mathrm{a}} z F E}{R T}\right) c_{\mathrm{CuCl}_{\mathrm{n}}^{1-\mathrm{n}}}- \\
& z F k_{\mathrm{c}}^{\mathrm{o}} \exp \left(\frac{-\alpha_{\mathrm{c}} z F E}{R T}\right) c_{\mathrm{Cu}^{2+} c_{\mathrm{Cl}^{-}}}{ }^{\mathrm{n}}
\end{aligned}
$$

At equilibrium, the partial current density for the cathodic and anodic reactions is equal and opposite sign. The exchange current density at the equilibrium potential can be simplified to

$$
\begin{aligned}
& j_{\mathrm{o}}=z F k_{\mathrm{a}}^{\mathrm{o}} \exp \left(\frac{\alpha_{\mathrm{a}} z F E_{\mathrm{e}}}{R T}\right) c_{\mathrm{CuCl}_{\mathrm{n}}^{1-\mathrm{n}}}= \\
& -z F k_{\mathrm{c}}^{\mathrm{o}} \exp \left(\frac{\alpha_{\mathrm{c}} z F E_{\mathrm{e}}}{R T}\right) c_{\mathrm{Cu}^{2+} c_{\mathrm{Cl}^{-}}{ }^{\mathrm{n}}}
\end{aligned}
$$

where $j_{\mathrm{o}}$ is the exchange current density and $E_{\mathrm{e}}$ is the equilibrium potential. The base 10 logarithmic form of the forward, cathodic reaction in equation (14) is

$$
\log j_{\mathrm{o}}=S^{-1} E_{\mathrm{e}} \log \left(-z F k_{\mathrm{c}}^{\mathrm{o}} c_{\mathrm{Cu}^{2+}}\right)+n \log c_{\mathrm{Cl}^{-}}
$$

where $S$ is the Nernstian slope $(S=2 \cdot 303 R T / z F$ which is $58.7 \mathrm{mV}$ at $296 \mathrm{~K}$ for a one electron reduction).

Equation (15) indicates that a plot of $\log j_{\mathrm{o}}$ against $\log c_{\mathrm{Cl}^{-}}$should be linear. From Fig. 3b, the slope gave a stoichiometric number for the chloride ion, $n$ of $2 \cdot 02 \approx 2$, supporting the dichlorocuprous anion, $\mathrm{CuCl}_{2}^{-}$as the main species complexing with $\mathrm{Cu}(\mathrm{I})$ in the electrolyte.

Figure $4 a$ shows the effects of chloride ion concentration on the limiting current density for the reduction of $\mathrm{Cu}(\mathrm{II})$ to $\mathrm{Cu}(\mathrm{I})$ and $\mathrm{Cu}(\mathrm{I})$ to $\mathrm{Cu}(0)$. Three regions can be identified. At low chloride ion concentration,

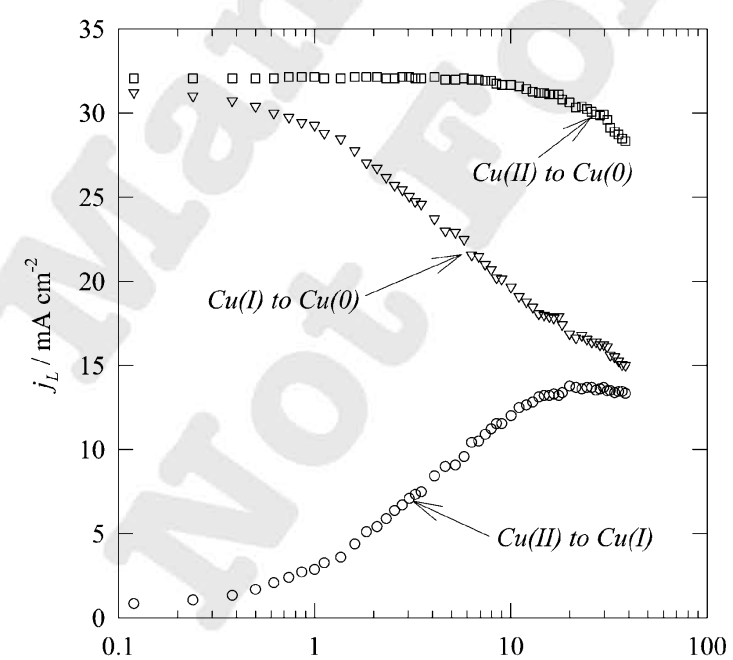

(a)

$\mathrm{c}_{C l} / \mathrm{c}_{C u^{2+}}$

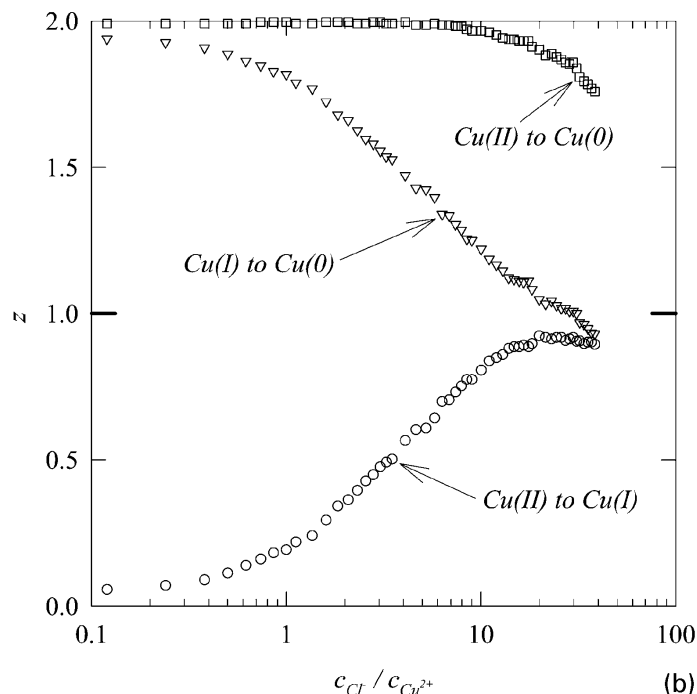

4 Influence of chloride ion concentration on a limiting current density for copper deposition from mixed chloride-sulphate electrolyte and $\boldsymbol{b}$ number of electrons involved in deposition reaction: $\bigcirc$ reduction of $\mathbf{C u}(\mathrm{II})$ to $\mathbf{C u}(\mathrm{I}), \nabla \mathbf{C u}(\mathrm{I})$ to $\mathrm{Cu}(0)$ and $\square \mathrm{Cu}(\mathrm{II})$ to $\mathrm{Cu}(0)$; diffusion coefficient for $\mathrm{Cu}(\mathrm{II})$ in absence of chloride ion was $4.5 \times 10^{-6} \mathrm{~cm}^{2} \mathrm{~s}^{-1}$; $4.0 \times 10^{-6} \mathrm{~cm}^{2} \mathrm{~s}^{-1}$ for $\mathrm{Cu}(\mathrm{II})$ in presence of chloride ion and $4.5 \times 10^{-6} \mathrm{~cm}^{2} \mathrm{~s}^{-1}$ for $\mathrm{Cu}(\mathrm{I})$ 
$c_{\mathrm{Cl}^{-}} / c_{\mathrm{Cu}^{2+}} \leq 1$ and the limiting current density increased marginally for reduction of $\mathrm{Cu}$ (II) to $\mathrm{Cu}(\mathrm{I})$ then decreased slightly for the $\mathrm{Cu}(\mathrm{I})$ to $\mathrm{Cu}(0)$ reaction. At an intermediate concentration ratio, $1 \leq c_{\mathrm{Cl}^{-}} / c_{\mathrm{Cu}^{2+}} \leq 10$, the limiting current density further increased for $\mathrm{Cu}$ (II) to $\mathrm{Cu}(\mathrm{I})$ then decreased for $\mathrm{Cu}(\mathrm{I})$ reduction to $\mathrm{Cu}(0)$. Linear curves can be obtained in this region, where the limiting current density for the reduction of $\mathrm{Cu}$ (II) to $\mathrm{Cu}(\mathrm{I})$ and $\mathrm{Cu}(\mathrm{I})$ to $\mathrm{Cu}(0)$ was varied approximately $9 \cdot 7 \mathrm{~mA} \mathrm{~cm}^{-2}$ per decade with respect to the chloride ion to copper ion concentration. At relatively high chloride to copper ion concentrations, $c_{\mathrm{Cl}^{-}} / c_{\mathrm{Cu}^{2+}} \geq 10$, the limiting current density for the reactions reached a steady state condition.

The limiting current density for the reduction of $\mathrm{Cu}$ (II) to $\mathrm{Cu}(0)$, e.g. $30 \mathrm{~mA} \mathrm{~cm}^{-2}$, in the absence of chloride ion, was approximately twice that for the reduction of $\mathrm{Cu}$ (II) to $\mathrm{Cu}(\mathrm{I})$ and for $\mathrm{Cu}(\mathrm{I})$ to $\mathrm{Cu}(0), 15 \mathrm{~mA} \mathrm{~cm}^{-2}$, in the presence of chloride ion. The limiting current density for $\mathrm{Cu}(\mathrm{II})$ to $\mathrm{Cu}(0)$ is lowered at high chloride ion compared with low chloride ion, e.g. at $0.05 \mathrm{~mol} \mathrm{dm}^{-3} \mathrm{Cl}^{-}$, the limiting current density was approximately $32 \mathrm{~mA} \mathrm{~cm}^{-2}$; at a $1.92 \mathrm{~mol} \mathrm{dm}^{-3} \mathrm{Cl}^{-}$ion concentration, the limiting current density was approximately $28 \mathrm{~mA} \mathrm{~cm}^{-2}$. A similar observation was also reported; e.g. less copper was deposited onto a porous silica substrate from a solution containing $0.01 \mathrm{~mol} \mathrm{~L}^{-1}$ copper ion in trifluoromethanesulphonic acid, at an $\mathrm{NaCl}$ concentration $>0 \cdot 1 \mathrm{~mol} \mathrm{dm}^{-3} \mathrm{Cl}^{-}$. Copper deposition was found to be progressively inhibited as the concentration of $\mathrm{Cl}^{-}$ increased in the solution. ${ }^{34,35}$ Assuming diffusion coefficients of $4.5 \times 10^{-6} \mathrm{~cm}^{2} \mathrm{~s}^{-1}$ for $\mathrm{Cu}$ (II) in the absence of chloride ion; $4.0 \times 10^{-6} \mathrm{~cm}^{2} \mathrm{~s}^{-1}$ for $\mathrm{Cu}$ (II) in the presence of chloride ion and $4.5 \times 10^{-6} \mathrm{~cm}^{2} \mathrm{~s}^{-1}$ for $\mathrm{Cu}(\mathrm{I})$ ions, the number of electrons involved in each reduction step can be estimated, as shown in Fig. $4 b$. The trends are similar to those shown in Fig. $4 a$. The presence of $\mathrm{Cu}(\mathrm{I})$ species during copper deposition progressively became more important as chloride addition to the sulphate electrolyte was increased.

\section{Conclusions}

1. Mixed chloride-sulphate acidic electrolytes containing $0.05 \mathrm{~mol} \mathrm{dm}^{-3} \mathrm{CuSO}_{4}$ and $0.5 \mathrm{~mol} \mathrm{dm}^{-3} \mathrm{Na}_{2} \mathrm{SO}_{4}$ corrected to $\mathrm{pH} 2$ with $\mathrm{H}_{2} \mathrm{SO}_{4}$ and 0.03 to $2 \cdot 0 \mathrm{~mol} \mathrm{dm}^{-3} \mathrm{NaCl}$ at $296 \mathrm{~K}$ were investigated. Linear sweep voltammetry was used to study the influence of chloride ion on the voltammetry of copper deposition using a platinum rotating disc electrode.

2. Under controlled flow conditions at a rotating disc electrode, the reduction of $\mathrm{Cu}(\mathrm{II})$ to $\mathrm{Cu}(0)$ involved the simultaneous transfer of two electrons in a sulphate bath and the $\mathrm{Cu}(\mathrm{II})$ to $\mathrm{Cu}(\mathrm{I})$ to $\mathrm{Cu}(0)$ system showed the increasing importance of $\mathrm{Cu}(\mathrm{I})$ species when a sufficient chloride ion concentration was present.

3. Steady state, linear sweep voltammetry showed a transition from a single limiting wave in pure sulphate electrolyte to two limiting waves in mixed chloridesulphate electrolyte. The presence of $\mathrm{Cu}(\mathrm{I})$ ions became increasingly important when sufficient chloride ion was added to the sulphate electrolyte.

4. Linear relationships between the chloride ion concentration with exchange current density, open circuit potential, half-wave potential for $\mathrm{Cu}$ (II) to $\mathrm{Cu}(\mathrm{I})$, start potential and potential region for complete mass transport control of $\mathrm{Cu}(\mathrm{I})$ to $\mathrm{Cu}(0)$, were obtained. The presence of the dichlorocuprous anion, $\mathrm{CuCl}_{2}^{-}$became dominant when the molar concentration ratio of chloride to copper ion exceeded 2.

\section{References}

1. C. T. J. Low, C. Ponce de León and F. C. Walsh: Aust. J. Chem., $2005, \mathbf{5 8}, 246$

2. F. A. Lowenheim: 'Modern electroplating', 183-203; 1974, New York, John Reilly \& Sons.

3. N. M. Martyak, M. D. Gernon and P. Janney: 'Electroplating of copper from alkanesulphonate electrolytes', US 6605204, Atofina Chemical Inc., August 2003.

4. C. T. J. Low and F. C. Walsh: Surf. Coat. Technol., 2008, 202, 3050-3057.

5. V. W. Christel, S. Marco, K. Marlies and H. Joachim: 'Method for electrolytic deposition of metal', JP2006063450, March 2006.

6. P. M. Vereeken, R. A. Binstead, H. Deligianni and P. C. Andricacos: IBM J. Res. Dev., 2005, 49, 3

7. J. P. Healy, D. Pletcher and M. Goodenough: J. Electroanal. Chem., 1992, 338, 155.

8. J. J. Kelly and A. C. West: J. Electrochem. Soc., 1998, 145, 3472.

9. J. J. Kelly and A. C. West: J. Electrochem. Soc., 1998, 145, 3477.

10. Y. Cao, P. Taephaisitphonse, R. Chulpa and A. C. West: J. Electrochem. Soc., 2001, 148, C466.

11. P. Taephaisitphonse, Y. Cao and A. C. West: J. Electrochem. Soc., 2001, 148, C492

12. N. Tantavichet and M. D. Pritzker: Electrochim. Acta, 2005, 50, 1849.

13. L. Bonou: Electrochim. Acta, 2002, 47, 4139.

14. W. P. Dow, H. S. Huang, M. Y. Yen and H. C. Huang: J. Electrochem. Soc., 2005, 152, C425.

15. M. Ishikawa, H. Hagiwara and R. Kimizuka: US 6518182, 2003.

16. P. M. Vereeken, R. A. Binstead, H. Deligianni and P. C. Andricacos: IBM J. Res. Dev., 2005, 49, 3

17. C. Gabrielli, P. Moçotéguy, H. Perrot, D. Nieto-Sanz and A. Zdunek: Electrochim. Acta, 2006, 51, 1462.

18. P. M. Vereeken, R. A. Binstead, H. Deligianni and P. C. Andricacos: IBM J. Res. Dev., 2005, 49, 3 .

19. W. Liu and D. C. McPhail: Chem. Geo., 2005, 221, 21

20. M. Lundström, J. Aromaa, O. Forsén, O. Hyvärinen and M. H. Barker: Hydrometallurgy, 2007, 85, 9.

21. A. J. Cobley and D. R Gabe: Circuit World, 2001, 27, (3), 19-25.

22. M. R. H. Hill and J. Rogers: Electroanal. Chem., 1978, 86, 179

23. T. Pearson and J. K. Dennis: J. Appl. Electrochem., 1990, 20, 196. 24. T. M. Tam and P. J. Christensen: Plat. Surf. Finish., 1998, 75, (3), 70 .

25. Z. Nagy, J. P. Blaudeau, N. C. Hung, L. A. Curtiss and D. J. Zurawski: J. Electrochem. Soc., 1995, 142, L87.

26. B. Bozzini, L. D'Urzo, C. Mele and V. Romanello: J. Mater. Sci. Mater. Electron., 2006, 17, 915.

27. U. Bertocci: Electrochim. Acta, 1966, 11, 1261.

28. D. Pletcher: 'A first course in electrode processes', 2nd edn, Royal Society of Chemistry, Cambridge, 2009.

29. F. C. Walsh: 'A first course in electrochemical engineering', The Electrochemical Consultancy, Romsey, 1993.

30. J. Malyszko and M. Kaczor: J. Chem. Educ., 2003, 81, (9), 1048.

31. C. Ponce de Leon and F. C. Walsh: Trans. IMF, 2003, 81, B95B100.

32. J. Albery: 'Electrode kinetics', 149; 1975, London, Oxford University Press.

33. A. J. Bard and L. R. Faulkner: 'Electrochemical methods: fundamentals and application', 2nd edn; 2001, New York, John Wiley \& Sons

34. F. A. Harraz, T. Sakka and Y. H. Ogata: Electrochim. Acta, 2002, 47, 1249.

35. J. Sasano, J. Jorne, N. Yoshimi, T. Tsuboi, T. Sakka and Y. H. Ogata: Proc. Symp. on 'Fundamental aspects of electrochemical deposition and dissolution including modeling, Vol. 84; 2000, Pennington, NJ, The Electrochemical Society. 